\title{
Chapter 10 \\ The 2011 Crisis in Italy: A Story of Deep- Rooted (and Still Unresolved) Economic and Political Weaknesses
}

\author{
Simone Romano
}

\begin{abstract}
Italy went through an economic and political crisis in 2011. The trigger was the Sovereign debt crisis that shook the Eurozone due to its incomplete structure. The ingrained causes were the long-term structural problems that have plagued the Italian economy for a long time, leaving it vulnerable to external shocks. The reaction to the crisis took the form of austerity measures and reforms implemented by a technocratic Government. These policies, carried out with no external financial assistance, were meant to send a signal to markets and stop the spiral of distrust and negative self-fulfilling expectations, but they did not address the sources of the problems. Since then much has been done at both national and European levels, but it is still not enough to guarantee resilience. Italy needs to finally solve its structural problems, and the European Monetary Union (EMU) needs to complete its architecture, starting with the completion of the Banking Union. Considering the increasing social discontent and political intolerance, failing to act now might imply severe consequences when the next crisis hits.
\end{abstract}

\section{When Did the Crisis Start? International Triggers and National Ingrained Causes}

On the 16th of November 2011, the Government headed by Mario Monti took office, replacing the Cabinet presided over by Silvio Berlusconi. This change in the political leadership, due to the state of emergency and not to standard political dynamics, is the clearest symbol of the economic and political crisis which Italy went through in 2011 (Bosco and McDonnell 2012). It is certainly not the starting point though. That crisis was due to both cyclical and structural conditions and to national and international factors, making it a deep-rooted and complex phenomenon, whose causes and origins are not easy to pinpoint.

\footnotetext{
S. Romano $(\bowtie)$

G7/G20 Sherpa Unit, Office of the Prime Minister of Italy, Rome, Italy

e-mail: simone.romano@uniroma3.it 
At the beginning of November 2011, the spread that measures the difference between the 10-year treasury bond yields of Italy and Germany was at 574 basis points, while at the beginning of that same year, it was 400 basis points lower. This worrisome dynamic was self-sustaining, fostering a vicious cycle of negative selffulfilling expectations about the soundness of Italian public finances. These negative expectations contributed to plunge the country into a second and longer recession, after the one that followed the 2008 financial crisis, which, in turn, replenished the pessimistic predictions (Henningsen 2012). Albeit Italy had run larger budget deficits and had borrowed with substantial higher interest rates in its recent years, ${ }^{1}$ the unfolding of the events in 2011 urged an unprecedented move, such as the change of government. Was the heavy public debt burden the driving cause of this negative spiral? Was the contagion of the crisis that had started in Greece the precedent year? Was it the lack of confidence towards the Italian government? Was it the structural weakness of the Italian economy? As a matter of fact, the 2011 crisis in Italy was the result of a complex combination of different causes, with short-run external triggers building on national long-run problems.

The international context played a key role in exacerbating the negative perception over a national economic situation that, albeit not sound and prosperous, in other circumstances would have been judged far away from the possibility of a sovereign default. The so-called Sovereign Debt Crisis of 2011 started in Greece the precedent year and was triggered by the Greek reckless handling of public finances, hiding a prolonged period of overspending through "books-cooking" practices. This crisis though, as described by Baldwin and Giavazzi (2015), was not only explainable in terms of sovereign debt (un)sustainability, but it was rather originated by growing and undisputed imbalances that developed over time in the European Monetary Union (EMU) since its inception. The unfolding of the crisis enlightened the flawed nature of the EMU due to its incomplete construction: without adequate tools at the European level to curb the contagion, when the Greek problem exploded, the financial markets promptly started fearing about the resilience of other national economies that for many reasons seemed less equipped to counteract the negative shock spread by the collapse of the Greek economy throughout the Eurozone.

As Fig. 10.1 illustrates, while for Portugal, Ireland and Spain the main problem was the soaring level of deficit due to the bailout of key actors of their banking and financial sector, for Italy, the Achilles heel was the high level of public debt (Fig. 10.2). ${ }^{2}$

\footnotetext{
${ }^{1}$ While the peak for the interest rates on the Italian Government Bond registered in December 2011 was around $7 \%$, the interest rate on the same security was around $21 \%$ at the end of 1981 (IMF Database). In that year, Italy had a public deficit of around $10 \%$ of GDP, so higher than the ones registered in the period 2009-2011, when the peak was around 5\% (EU Commission dataset).

${ }^{2}$ The higher level of primary deficit (and so of public debt) registered in Italy in the aftermath of the global financial crisis was not due to discretionary fiscal stimulus or bailouts, but mainly it was the result of the slowdown of the economy and its consequent pressure on public budget through automatic stabilizers.
} 


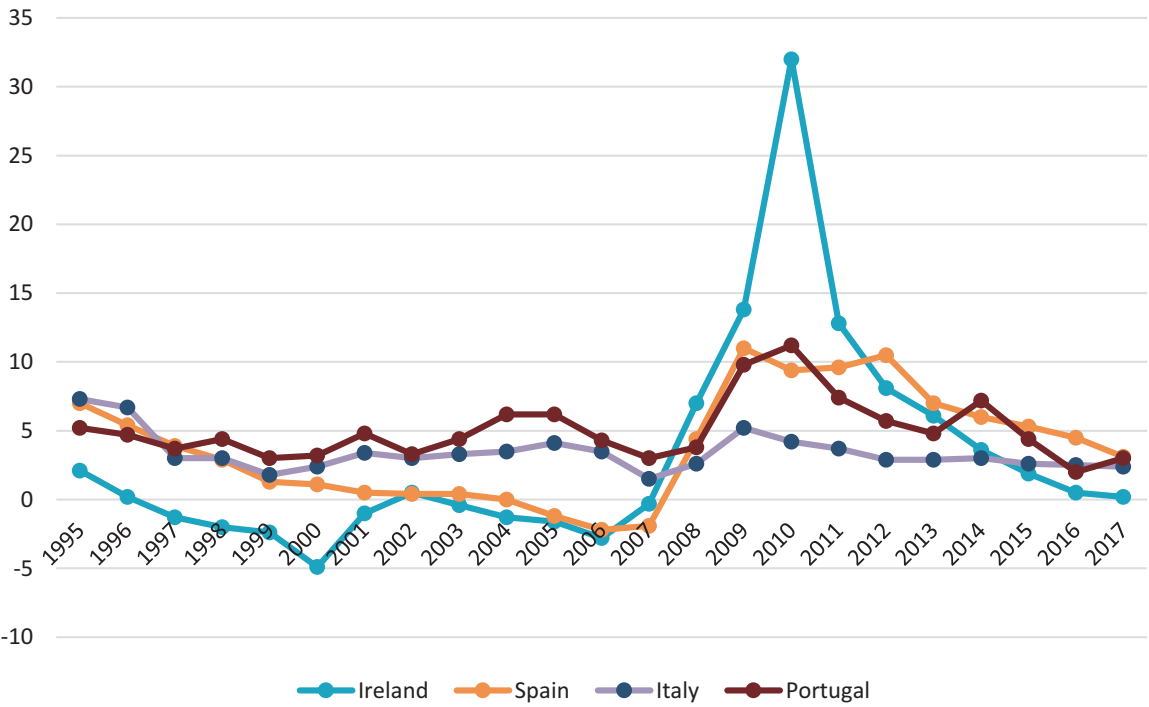

Fig. 10.1 Deficit levels (as \% of GDP). (Source: Eurostat)

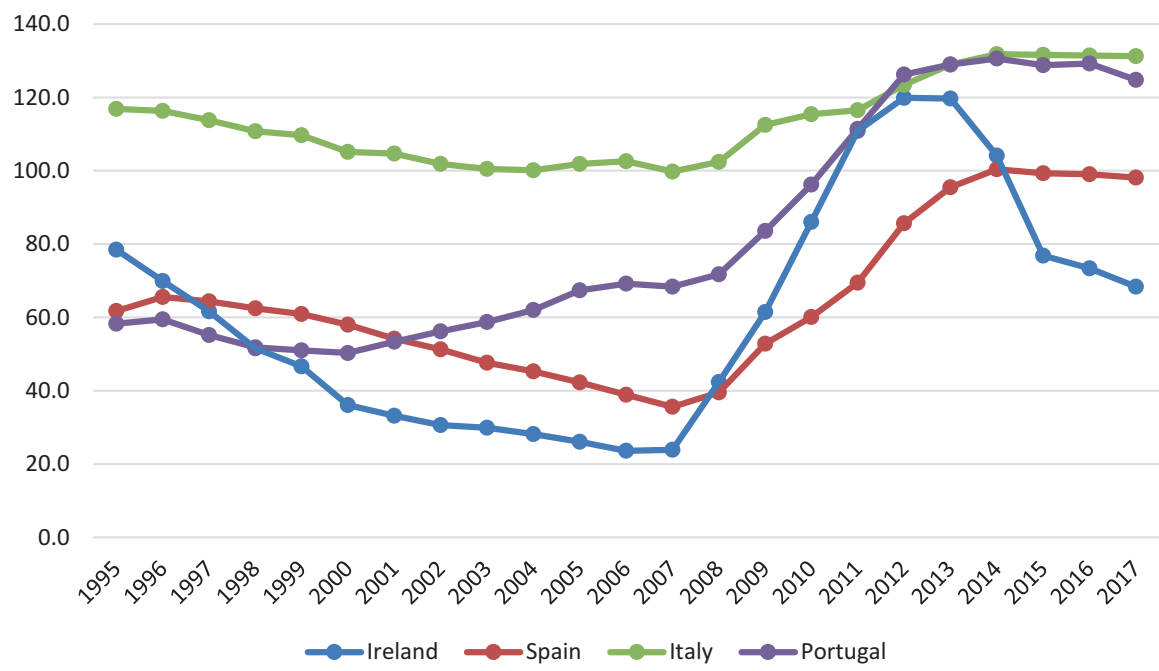

Fig. 10.2 Public Debt (as \% of GDP). (Source: Eurostat)

The mounting lack of confidence towards the resilience of the Italian public finances was fuelled by national characteristics as well: the widespread mistrust towards the Government and its capability of guiding the country in such a difficult moment and the long-term structural weaknesses of the Italian economy, such as the low productivity growth and the high level of unemployment, tax avoidance and corruption. All of this quickly fostered the view that Italy could be one of the next 
EMU member countries to face a situation similar to the one that was happening in Greece, spreading fears about its ability to honour its sizeable sovereign debt.

Against this background, with the spread sailing straight to the 400 basis point, on the 5th of August 2011 the European Central Bank (ECB) sent a letter, meant to be secret, to the Italian government. The missive, signed by both Trichet and Draghi, urged the Italian government to act baldly and swiftly. Among the urgent measures advised by the ECB were the increase in competition to foster efficiency and strengthen economic growth, large-scale liberalization and the decentralization of wage bargaining. Albeit the government headed by Silvio Berlusconi promptly reacted, starting immediately to implement some of these measures, many European political leaders - above all the German Chancellor Angela Merkel and the French President Nicolas Sarkozy - thought it was not enough. This judgement was shared by investors, which were increasingly reluctant to buy Italian Treasury Bonds, driving up interest rates and spread. The publication of the Trichet-Draghi letter in the late September by an important Italian newspaper did not help to cool the situation off, eroding the thin confidence on which the cabinet was hinging. At this point, a strong signal was needed: the change in government was the inevitable last resort.

The described unfolding of events demonstrates the key role played by both the flaws in the architecture of the EMU that paved the way for the 2011 crisis, and the long-standing fragility of the Italian economy. The next two paragraphs briefly extend the analysis on both factors.

\section{Deep-Rooted National Weaknesses}

The Italian economy has been dragged down for long time by structural problems that all Governments, regardless of their political colour, have struggled to solve or even just to address.

Italy is one of the countries with the highest level of value-added tax (VAT) avoidance in Europe, and it has faced the problem of generalized tax evasion for a long time. This phenomenon coupled with the wide dimension of its black economy subtracts important resources from the public budget, exacerbating its fiscal sustainability issues.

The narrow fiscal space that these factors shape is detrimental for economic growth. Italy has difficulties in attracting private capitals: the scarce efficiency in its bureaucracy and judiciary system together with the high level of corruption scares away international investors, while the uncertainty stemming from its chronic political instability discourages national investment. Since the lack of investment depresses the productivity growth, Italy needs public investment, but the government cannot afford to step in because of its tight budgetary constraints (Henningsen 2012).

All of this is coupled with an inefficient labour market where, moreover, the portion of graduates in the work force is very small if compared with other advanced economies. The sluggish or flat economic growth resulting from these factors increases the debt burden, requesting a very tight budgetary policy to maintain its 
dynamics under control. This policy does not sustain aggregate demand and growth, further fuelling the vicious circle.

\section{International Context}

The EMU is a unique case of a currency union without a centralized fiscal policy design. This implies that the common monetary policy can deal only with unionwide shocks, while the reaction to idiosyncratic shocks is left in the hands of national policies. Even though these national policies may be not enough, the Eurozone lacks union-wide stabilizers: the labour and capital mobility among member countries has been scarce, the level of coordination on the union-wide fiscal stance has not been sufficient and the EMU still lacks common fiscal capacity. In such environment, a sizeable national shock can easily become systemic as the Greek case of 2010-2011 clearly demonstrated.

This background is particularly worrisome in the light of the enhanced economic interdependence among member states due to the currency union and the common market: inside the EMU, many banks, funds and firms hold sovereign bonds of other member countries, and many firms do business with their counterparts in other member states. Hence, if a member state is to default on its debt or to face a deeply troublesome economic situation, its economy would not be the only one to be severely hit, but the shock would spread to other member countries through both financial and trade channels.

As a consequence, national Governments could be called to intervene to help distressed financial institutions or to avoid an ulterior slowdown of their economies. Many of these Governments, though, have budgetary positions which are already worrisome, as it was the case in 2010-2011, when many of them were already in dire straits. At this point, financial markets, which are forward looking for their own nature, started pricing in the higher risk. In 2011, these jitters were further fuelled by the famous and improvident Deauville beach walk, when President Sarkozy and Chancellor Merkel decided that the private sector had to bear part of the burden in case of sovereign defaults. Albeit the decision could be right in principle, the timing was highly inappropriate and ended up igniting the financial contagion that transformed the Greek sovereign crisis into a union-wide crisis, hitting Italy as well (Haas and Gnath 2016).

\section{The Policy Responses: Austerity and Reforms}

When the Monti cabinet took office, the situation was highly distressed. Markets had lost confidence in the Italian capacity to honour its debt: the prices of the Italian Treasury bonds were collapsing, increasing the interest rate on the debt and, in turn, narrowing further the fiscal space. Time was ticking and a strong signal was needed 
to calm the markets and show that the new Italian leadership was able to steer away from disaster.

The strong response took the form of the so-called "Salva Italia" (Saving Italy) decree, launched by the Cabinet just roughly 2 weeks after its appointment. The timing of the decree, the fact that the budgetary law there contained was the fifth of the year and the sizeable net balance (with a net surplus of 20 billion euros) well describe the scope and the urgency of this manoeuvre.

The decree comprised three chapters: public budget, social security and growth. The spending cuts were crafted to reach the amount of 12-13 billion euros in 3 years, while the increase in taxes was designed to bring new revenues in the amount of 17-18 billion in the same time span. Of this grand total of 30 billion euros, 20 of them were thought to be used to reduce the deficit (and so preventing the debt from soaring), while 10 were destined to growth-enhancing measures (Baldini 2014).

On the spending reduction side, the Salva Italia decree provided for a radical change in the role of the provinces as territorial administrations, diminishing their competences as a first and quicker step towards their complete abolition. ${ }^{3}$ On the same line, the decree reduced the number of employees of all the authorities, while many of the existent authorities were abolished.

Remaining in the first chapter, on the revenue side, the real estate taxation, already introduced, was anticipated (so as to start in 2012 and no longer in 2014), and it was extended to first homes as well. Furthermore, a luxury tax was introduced on cars, boats and private aircrafts. The VAT was designed to increase from $21 \%$ to $23 \%$ in 2012 but, in the end, only increased to $22 \%$ during the Government headed by Enrico Letta, in 2013.

The most important measure for its long-term impact was contained in the second chapter: social security. The retirement reform known as Fornero law (from the name of the Ministry who crafted it) changed the former defined benefit pension scheme into a defined contribution pension scheme. It also raised the retirement age and provided incentives for people who postpone their retirement. This translated into a substantial long-term structural improvement of the Italian budgetary position, quickly making it one of the most honourable member countries for the EU Sustainability Index produced by the Marktwirtschaft Stiftung (2014), which takes into account not only the outstanding level of debt, but also its projection into the future.

Regarding the third chapter, the measures to spur economic growth were inspired by the need to improve the budgetary position as well, resulting in the usage of widespread liberalizations as the main tool. Just as a matter of example, the limits regarding the opening times for any kind of shop or commercial activity were abolished, and the territorial criteria determining the number of pharmacies were modified as to increase competition. Beyond liberalizations, the decree established as deductible the regional income tax paid by firms and employers on workers, and

\footnotetext{
${ }^{3}$ As of today, the provinces, albeit further modified, still exist and function.
} 
aimed at refinancing many public infrastructure projects considered key for future development (Culpepper 2014). Albeit for timing and scope the strongest response, the Salva Italia decree was not the only clear signal that the emergency cabinet sent to markets, investors and other political leaders. In fact, while already started by the former government, the parliament speeded up the approval of the balanced budget constitutional amendment, and the government proposed a spending review, meant to save up on unproductive expenditures, with a cut in the civil servants and military forces (among others).

To better understand the Italian response to the crisis, it is important to stress that, differently from Greece, Ireland, Portugal and Spain, Italy did not receive any financial assistance from the EU Commission or the International Monetary Fund (IMF). This implies that it did not have any external authority directly involved in the policy design. In the immediate aftermath of the Salva Italia decree, the spread, thermometer of the market sentiment towards Italy, decreased and reached 374 points. At the end of the year though, it increased again, reaching 500 points. In 2012 , the spread followed a fluctuating trend, with a new peak over 500 in the summer of 2012. This shows that while the austerity measures pushed by the Monti cabinet managed to avoid the worst from happening, breaking the negative spiral that threatened to plunge Italy into a sovereign debt crisis, they did not succeeded in solving the problem at its source but, truth be told, they were not meant to do so.

The problem with the Italian economy has been the passiveness used to address the underlying structural problems. This made a "shock therapy" in necessary the worst moment: in the context of 2011, with a huge slack in the economy and an accommodative monetary policy, the fiscal multiplier was bigger than usual (Chinn 2013). In these conditions, a stark package of austerity measures, albeit necessary in that moment of emergency, had a very negative and long-lasting effect on the already troubled Italian economy, prolonging the time needed to recover from recession and shaping what has been happening in the years up to now, both on the economics and politics. Even though a strong tightening of the public budget was inevitable in that difficult moment, a technocratic Government could have been braver in designing the measures, looking only at their long-time effect, with no need to consider the inevitable political discontent that they were to originate.

Despite the efforts, the 2011 crisis in Italy and the Eurozone was not over until the summer of 2012. In fact, the spread in the Eurozone as a whole (and so in Italy as well) decreased in a lasting and sizeable way only after the famous "Whatever it takes" speech pronounced by the ECB President Mario Draghi in July 2012. These words made history as the perfect example of the forward guidance tool aimed at shaping expectations, declaring that no matter the challenges, the ECB was ready to do whatever was needed to save the Euro and, quoting President Draghi, that would have been enough. As a matter of fact, it was.

The fact that only the intervention of a European power was able to solve the problem demonstrates how the 2011 Sovereign debt crisis was not only an issue of national public finances, but rather an EMU-wide problem. There is no doubt that Italy had a structurally flawed economic situation with a too high debt burden. This entailed that, sooner or later, in order to avoid a crisis, it would have been necessary 
to "put the house in order". The "house in order" approach indeed was-and still is - necessary to prevent the spreading of new crises in a currency union shaped as the EMU, calling each member state to be responsible and conscious of the spillover effects of its national economic policies. This said, what happened in the period 2010-2012 clearly demonstrated that the "house in order" approach, albeit necessary, is not sufficient, and a completion of the EMU architecture is desperately needed.

\section{The Economic and Political Legacy}

Seven years have passed from the peak of the crisis. Since then, much has been done to avoid repeating past mistakes, both at national and European levels. Nevertheless, it is not enough: many of the problems that led to the 2011 crisis, at both levels, are still unresolved. On the Italian side, it suffices to think that in the weeks that preceded the drafting of this paper, Italy lived a sort of strange deja-vu, with a growing attention (or rather mistrust) from financial markets and other member states towards the conduct of economic policy carried out by the Government. Once again, the capability of the Cabinet to face the economic challenges, linked with the very high level of public debt and the stagnating economic growth, was questioned. This led investors to ask for a higher premium when buying Italian bonds, ending up increasing the interest rates and pushing the spread beyond 300 points. The similarity with what happened in 2011 clearly indicates that the underlying structural problems have not been resolved.

The Governments that followed the Cabinet headed by Mario Monti were successful in maintaining the debt dynamic under control and bringing Italy outside recession, but the country has not succeeded in recovering the pre-crisis level. ${ }^{4}$ While many other Western and European countries have experienced a period of substantial growth in the last 2-3 years, with the pace of crisis-hit countries like Spain or Ireland outperforming Italy substantially, Italian economy did not manage to fuel a convincing growth. ${ }^{5}$

This further confirms that the structural problems that paved the way for the 2011 crisis are still unresolved. The productivity growth is still very low, and the level of investment, both public and private, is not sufficient. The unemployment, above all among young people, is still very high, ${ }^{6}$ creating a concrete risk of hysteresis that, together with ageing, can lower further the productivity and any prospect of growth.

\footnotetext{
${ }^{4}$ The level of real GDP in 2016 was still much lower than in 2006, roughly at the level of 2001. Please refer to the table in the appendix for all the detailed figures.

${ }^{5}$ Both Ireland and Spain experienced an annual growth rate of their real GDP that was higher than $3 \%$ in the period 2015-2017, while the Italian rate in the same period was hardly higher than $1 \%$ (OECD StatExtra Database).

${ }^{6}$ The unemployment rate had been higher than $10 \%$ until the end of 2017, while the youth unemployment rate has been higher than $30 \%$ (Eurostat and OECD).
} 
Corruption, inefficient bureaucracy and public administration are still there as well, together with the high public debt burden.

To worsen further the situation, the two crises and the long recession that followed left a heavy legacy that adds on to old structural problems. The long-lasting decline of economic activity implied a very high share of firm destruction. This exacerbated the unemployment problem and contributed to the mounting problem of non-performing loans (NPL), which jeopardized the resilience of the whole Italian financial system. The Italian banks were not heavily engaged in derivatives, and this left them in a better shape in 2008 if compared with other international counterparts. The deep and long recession that followed the 2008 financial crisis brought many borrowers to default on their debts or to be delinquent with their payments. This situation put a strain on the balance sheets of many Italian banks, creating a concrete threat for the resilience of the Italian banking sector. In turn, this problem affected the capability of financial institutions to lend to the real economy, curbing further economic growth.

While the worst phase of the NPL issue seems behind our backs as the peak of the 2011 crisis, the Italian economy is still in a bad shape. This long-standing difficult economic situation has important consequences that go beyond the economy, affecting the political and social spheres as well. The lack of a proper economic recovery together with the unpopular austerity measures approved as a solution to stop the contagion of 2011 created a fertile ground for the spread of populism. The absence of tangible positive results in face of the sacrifices that the austerity measures imposed to a big part of population has led people to become increasingly angry and disappointed at elites and the establishment. In an enduring period of uncertainty such as the present one, people have started seeking prompt protection and fast solutions. While standard political parties failed to understand and address these needs, the populist forces responded directly to the people requests, offering simple solutions and wide protection regardless of their real feasibility. This paved the way for the first openly populist Government in Italy, one of the founder and main member states of the EU. As demonstrated by the first 6 months of the populist Cabinet, this is not only an Italian problem but it spills over to the EU and the Eurozone. For the future of the EU construction, it is of paramount importance not to label this as a bump in the road or something strictly related to Italian dynamics. On the contrary, this has to be considered a wake-up call: the way the double crisis was handled had flaws and, in order to thrive, it is important to rethink social and economic policies at all levels.

Widening the focus to the European level, it is clear that the 2011 crisis has spurred an effort to provide the EMU with new and more adept instruments to face critical situations. To this end, the creation of the Banking Union and the European Stability Mechanism (ESM) are the two most important pillars. While in the aftermath of the crisis the pace for their creation was impressively quick and efficient, the impetus has lost momentum afterwards. The Banking Union provides the perfect example. What happened during the crisis highlighted the inadequacy of the national character of banking supervision in a common financial market where the main actors had a systemic importance. To this end, the Single Supervisory 
Mechanism (SSM) was created, shifting the competence for supervision of the systemic actors directly to the ECB. On top of this, the Single Resolution Mechanism was created, to handle in a homogenous way the solution of troubled systemic financial institutions. Although this effort has gone in the right direction, the construction has been left incomplete and, as it stands, it cannot function properly (exactly as it happened with the creation of the EMU). The third block of the Banking Union, the European Deposit Insurance Scheme (EDIS), needs to be created to diminish the probability of bank runs and self-fulfilling crises. Political divide between prioritizing risk reduction over risk sharing, or the way around, still hinders the creation of this third pillar, leaving the EMU exposed to shocks. The situation seems better on the ESM side, where a concrete reform of the international treaties shaping the ESM is currently under discussion, adding important features to the mechanism, such as its role of backstop for the Single Resolution Funds (SRF).

\section{What Have We Learned or What We Should Have Learned?}

The dynamics that led to the crisis of 2011, the unfolding of the events and the years that followed teach us important lessons for both Italy and Europe. At the Italian level, these years have stressed the importance to address the structural problems that have been ignored or badly addressed for too long, both in the economic and the political system. Policy uncertainty, lack of social capital, low productivity, increasing inequality, corruption and tax avoidance have been hampering the growth potential and policy stability for many years now. Addressing them only in a state of emergency, as it was the case in 2011, brings negative consequences that, considering the current economic and social situation in Italy, could be even worse. Moreover, these factors undermine Italy's economic and social resilience, making it very vulnerable to external shocks.

At the European level, the events of the last 7 years have showed the need to wisely complete the structure of the EMU, providing it with all the mechanisms that a currency union requires in order to function well. On a practical level, the first moves need to be the completion of the Banking Union, the revision and enhancement of the ESM and the provision of a fiscal capacity or any kind of fiscal stabilization tool at the European level (Shambaugh 2012).

None of these tasks is easy, none of them is free of high political costs, but if we do not act now, the cost in the future could be very high. A wise proverb states that the roof has to be repaired when the sun is shining. Now, with the positive economic moment of the last couple of years that is starting to fade, there is no longer room to postpone difficult decisions. Italy and the EMU have survived previous severe crises as the one in 2011, but, if they do not act baldly and swiftly to make their systems more resilient, they might be in deep trouble when the next crisis hits. The political and social capital has clearly eroded since 2011, and the economic situation, above all in Italy, offers less room for manoeuvre than in 2008. Errare humanum est, perseverare autem diabolicum. 


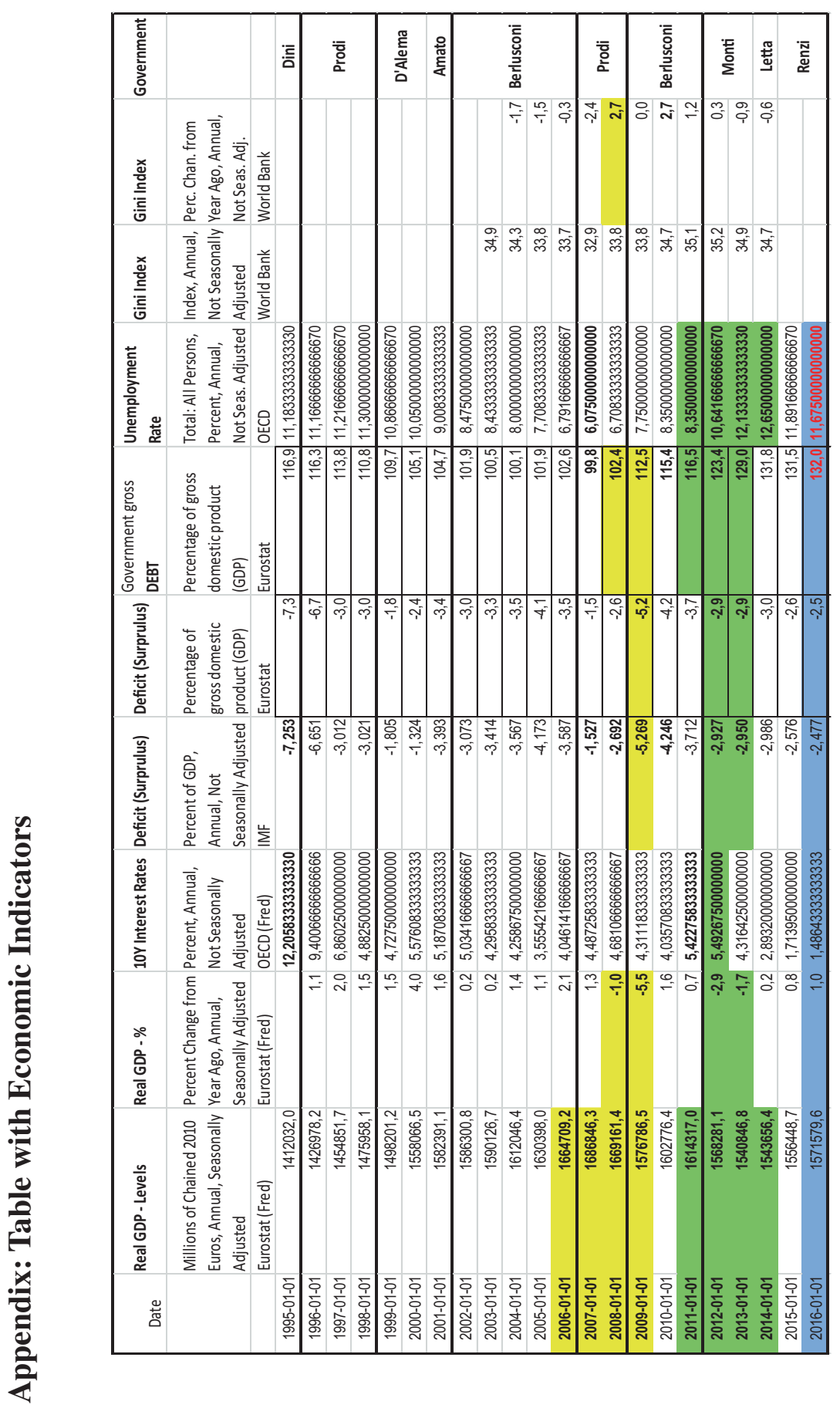




\section{References}

Baldini, M. (2014). Fiscal austerity and income distribution in Italy. Center for the Analysis of Public Policies (CAPP) 0112.

Baldwin, R., \& Giavazzi, F. (2015). The Eurozone crisis. A consensus view of the causes and a few possible solutions. VoxEu.org book.

Bosco, A., \& McDonnell, D. (2012). The Monti government and the downgrade of Italian parties. Italian Politics, 27(1), 37-56.

Chinn, M. (2013). Fiscal multipliers. The New Palgrave Dictionary of Economics, 7, 1-10.

Culpepper, P. D. (2014). The political economy of unmediated democracy: Italian austerity under Mario Monti, West European Politics, 37(6), 1264-81.

Haas, J., \& Gnath, K. (2016). The Euro area crisis: A short history. Bertelsmann Stiftung Policy Papers.

Henningsen, D. M. (2012). The origins of the Italian sovereign debt crisis. CMC Senior Theses Paper 379.

Marktwirtschaft Stiftung (2014). Honorable states? EU Sustainability Ranking, 2014.

Shambaugh, J. C. (2012). The Euro's three crises. Brookings Papers.

Open Access This chapter is licensed under the terms of the Creative Commons Attribution 4.0 International License (http://creativecommons.org/licenses/by/4.0/), which permits use, sharing, adaptation, distribution and reproduction in any medium or format, as long as you give appropriate credit to the original author(s) and the source, provide a link to the Creative Commons license and indicate if changes were made.

The images or other third party material in this chapter are included in the chapter's Creative Commons license, unless indicated otherwise in a credit line to the material. If material is not included in the chapter's Creative Commons license and your intended use is not permitted by statutory regulation or exceeds the permitted use, you will need to obtain permission directly from the copyright holder.

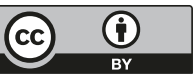

